\title{
Syntactic Priming Effects on Active and Passive Sentence Production in Persons with Aphasia: Evidence from an Eye-tracking Study
}

\author{
Mi Kyung Shin, Jee Eun Sung \\ Department of Communication Disorders, Ewha Womans University, Seoul, Korea
}

Correspondence: Jee Eun Sung, PhD Department of Communication Disorders, Ewha Womans University, 52 Ewhayeodae-gil, Seodamun-gu, Seoul 03760, Korea

Tel: $+82-2-3277-2208$

Fax: +82-2-3277-2122

E-mail: jeesung@ewha.ac.kr

Received: January 4, 2020

Revised: February 4, 2020

Accepted: February 12, 2020

This work was supported by the Ministry of Education of the Republic of Korea and the National Research Foundation of Korea (NRF2019R1A2C1089280).

This work was supported by Lee Seung Hwan's Scholarship from the Korean Academy of SpeechLanguage Pathology and Audiology in 2019.
Objectives: The purpose of this study was to investigate active and passive sentence production ability in aphasia by analyzing the process of sentence production under conditions of syntactic priming using eye-tracking. Methods: Nine patients with aphasia and ten age and education matched normal adults participated in this study. Participants repeated prime sentences first, and then described picture events using the same verb. Accuracy and speech onset latencies from speech regions (NP1-NP2-V-End) were analyzed and fixation count of areas of interest (Agent, Theme) from speech regions (Before onset, NP1, NP2, V-End) were analyzed for eye movement measurement. Results: Aphasic patients performed significantly less accurately than normal adults in both active and passive sentences; and they also took significantly longer to produce both type of sentences accurately. Similar fixation pattern was found between normal adults and aphasic patients when they made correct responses. However, when aphasic patients made wrong responses, the fixation pattern was different from correct responses' in normal adults and aphasic patients. Conclusion: The results of eye movement measurements suggests that eye movements of aphasic patients were similar to those of normal adults in correct response; fixating 'Theme' more than 'Agent'. On the other hand, in the case of incorrect responses, eye movements of aphasic patients were different from those of normal adults; indicating that aphasic patients have difficulties in processing active and passive sentence.

Keywords: Eye-tracking, Active and passive sentence production, Aphasia, Syntactic priming
실어증이란 정상적으로 언어를 습득한 사람의 중추 신경계가 손 상을 받아 그로 인해 언어를 표현하거나 이해하는 등의 다양한 영 역에서 효율성이 저하된 상태를 말한다(McNeil \& Pratt, 2001). Luria (1964)는 언어는 일종의 신경계 네트워크에 의해 수행되며, 뇌의 여러 영역이 언어기능의 수행에 동원되며 어느 한 부분이 손 상되면 언어기능의 장애가 나타난다고 하였다. 실어증 환자들은 언 어 처리과정의 효율성 저하로 인하여 전반적인 혹은 특정한 언어 능력의 상실을 경험하게 되고 이로 인해 문장 이해 및 문장 산출 과 정에서 결함을 보인다. 실어증 환자의 문장 산출에 대한 어려움은 선행연구에서 여러 차례 보고되었다.

실어증 환자들의 자발화를 분석한 결과, 실어증 환자들은 짧고 구문적으로 간결한 발화를 주로 사용하는 것으로 나타났으며 서
술어가 취하는 명사 논항 중에 서술어에 적합한 의미 관계를 결정 하는 의미역 할당과 문법적 요소의 사용에서 빈번하게 오류를 보 였다(Saffran, Berndt, Schwartz, 1989; Bird \& Franklin, 1996; Thompson et al., 2013; Rochon, Saffran, Berndt, \& Schwartz, 2000). 또한, 실어증 환자들은 구조화된 문장 산출과제에서도 다양한 결함을 보이는 것으로 나타났다(Caplan \& Hanna, 1998; Faroqi-Shah \& Thompson, 2003; Bastiaanse \& Edwards, 2004; Thompson \& Lee, 2009; Thompson et al., 2013). 특히, 구문적으로 간결한 능동문보 다는 피동문과 같이 복잡한 형태의 문장을 산출할 때 더 큰 어려움 을 보이는 것으로 나타났다(Faroqi-Shah \& Thompson, 2003; Burchert, Meißner, \& De Bleser, 2008; Thompson \& Lee, 2009; Thompson et al., 2013). 한국어를 사용하는 실어증 환자를 대상으로 한 선 
행연구에서도 실어증 환자들이 피동문의 이해와 산출에서 어려움 을 보인다고 보고하고 있다(Sohn, 2004; Choi, 2012; Sung, Eom, \& Lee, 2018).

실어증 환자들이 문장 산출에서 보이는 결함은 불완전하거나 손상된 구문 표상능력에 기인한다고 보거나(Friedmann \& Grodzinsky, 1997), 문법적 요소의 처리과정에서의 결함으로 보거나(Burchert et al., 2008; Cho \& Thompson, 2010; Lee, Yoshida, \& Thompson, 2015) 또는 더 일반적인 처리과정의 결함으로 설명하기도 한다 (Kolk, 1995). Schwartz, Saffran, Fink, Myers 그리고 Martin (1994) 은 실어증 환자들이 피동문을 산출할 때 통사구조적으로 문법적 인 요소(주어, 목적어)와 그에 따른 의미역(행위자, 대상)을 적절하 게 연결하는데 있어 결함을 보이기 때문에 피동문의 산출에 어려 움을 겪는다고 보고했다.

반면, 피동문 산출의 결함이 통사구조적 결함보다는 형태론적 결함에 기인한다고 보는 연구들도 존재한다(Caplan \& Hanna, 1998; Faroqi-Shah \& Thompson, 2003). 예를 들어, Caplan과 Hanna (1998)는 14 명의 실어증 환자를 대상으로 능동문과 피동문의 의미 역과 피동문의 형태론적 요소의 관계를 분석한 결과, 능동문보다 피동문에서 의미역 산출의 어려움을 보였으며 문법형태소의 산출 을 의미역 할당보다 더 어려워하는 것으로 나타났다. 반면, 형태론 적 결함보다 의미역 할당의 어려움이 더 크다고 주장하는 연구들 은 피동문 산출에서 나타나는 오류의 대다수가 의미역 전환(Role Reversals)으로 나타나며 피동문의 구조를 만드는데 피동문의 형 태론적 요소가 중요하게 작용하지 않을 때에도 의미역 할당에 어려 움을 보인다고 말한다(Bastiaanse \& Edwards, 2004; Bastiaanse, Edwards, Mass, \& Rispens, 2003). 또한, 피동문의 형태론적 결함 에 대해 보고한 선행연구들은 문장 산출 시 문장을 시작하는 첫 명 사를 제공하여 의미역 전환이 드물게 일어났을 가능성이 있다는 한계를 가지고 있다(Caplan \& Hanna, 1998; Faroqi-Shah \& Thompson, 2003).

이처럼 실어증 환자가 능동문보다 피동문에서 이해와산출에 어 려움을 보이는 원인을 설명하기 위해 많은 가설이 제시되고 있으며 이러한 가설 중에 어떠한 주장이 맞는가에 대해서는 논쟁과 검증 이 계속되고 있다. 국내에서 실어증 환자를 대상으로 능동 및 피동 문장의 이해와 산출 능력을 살펴본 기존의 연구들은 대부분 정반 응 수와 반응 시간 측정에 국한되어 실어증 환자가 실시간으로 자 극을 어떻게 처리하는지 알기 어렵다는 한계가 있다. 이에 대한 대 안으로 시선추적기법을 사용하여 실어증 환자의 실시간 문장 처리 과정을 살펴볼 필요가 있다. 시선추적기를 활용한 연구는 대상자 가 모니터에 나온 그림 자극을 보고 문장을 산출하게 하는 동안, 대
상자의 안구 움직임을 추적하여 다양한 문장 산출 구간에서 화면 의 어느 부분을 보고 말하고 있는지를 파악해 실시간 문장 처리 과 정과 그와 관련된 언어적 요소에 대한 통찰력을 제공한다(BrownSchmidt \& Tanenhaus, 2006; Griffin, 2004; Griffin \& Bock, 2000; Meyer \& Lethaus, 2004). 영어권에서는 시선추적기를 활용하여 실 어증 환자의 문장 처리과정을 실시간으로 보는 연구가 다양하게 진 행되고 있으며, 시선추적기법은 실어증 환자의 이해와 산출을 알아 보기에 적합한 방법으로 알려져 있다(Thompson \& Choy, 2009; Thompson, Dickey, Cho, Lee, \& Griffin, 2007; Lee \& Thompson, 2011; Lee et al., 2015).

Cho 와 Thompson (2010)은 시선추적기를 사용하여 9명의 실어 증 환자(실어증 지수 범위: 71.2-82.4, 유창성 범위: 4-6)들을 대상으 로 구문 점화 과제에서 그림 자극을 보고 능동 및 피동 문장을 산 출하는 과정에서 나타나는 안구 운동을 추적하였다. 이를 통해 실 어증 환자들이 피동문을 산출하는 과정에서 보이는 결함을 밝히 고자 하였다. 그 결과, 실어증 환자들은 피동문을 산출할 때 문장 산출 구간별로 산출한 첫 명사에 대한 시선고정 시간이 정반응과 오류 유형에 따라 다른 패턴을 보이는 것으로 나타났다. 의미역을 반대로 할당하여 말한 의미역 할당 오류와 피동문을 능동문으로 바꾸어 말한 문장 유형 전환 오류에서 나타난 시선고정 시간 패턴 은 정반응을 했을 때 나타난 시선고정 시간 패턴과 다른 것으로 나 타났다. 이를 통해 실어증 환자들이 피동문 산출에서 오류를 보일 때, 문장 계획과 산출 과정이 정반응을 할 때와 질적으로 다른 양 상으로 이루어진다고 하였다.

Mack과 Nerantzini 그리고 Thompson (2017)은 정상 성인과 실 어증 환자(실어증 지수 범위: 58.8-91.3)를 대상으로 피동문 산출에 중점을 둔 12 주간의 언어중재에 따른 피동 문장 및 능동 문장 산출 의 변화를 알아보기 위해 시선추적 연구를 실시하였다. 시선추적 실험은 언어중재를 받기 전과 언어중재를 받은 후에 2 번씩, 4 번에 걸쳐 진행되었다. 그 결과, 정상 성인의 경우 능동 및 피동 문장을 산출하기 전에 주어가 될 의미역을 주로 응시하는 것으로 나타났 다. 실어증 환자의 경우, 언어중재를 받기 전보다 받은 후에 정반응 률이 유의하게 높아졌으며 시선추적 결과에서도 언어중재를 받기 전에는 능동문과 피동문의 산출 과정에서 행위자에 대한 시선고 정 비율이 문장 유형에 따라 달라지지 않고 거의 비슷한 패턴을 보 였지만 언어 중재를 받은 후에는 문장을 산출하기 전 주어가 될 의 미역을 주로 응시하여 정상 성인과 비슷한 형태로 변화하였다. 언 어중재를 받지 않은 실어증 환자군에서는 이러한 변화가 나타나지 않아 피동문 산출에 중점을 둔 언어 중재가 실어증 환자군에게 효 과적인 것으로 나타났다. 
Cho와 Thompson (2010)의 연구와 Mack 등(2017)의 연구를 살 펴본 결과, 실험에 참여한 실어증 환자의 실어증 중증도(Aphasia Quotient, $\mathrm{AQ}$ ) 점수만 제공하고 있으며 실어증 환자들을 실어증 유형으로 분류하지 않았다. McNeil과 Pratt (2001)에 따르면 실어 증 병소 부위와 실어증 유형에 따라 특정 언어증상이 고정되어 나 타나는 것이 아니기 때문에 실어증 유형만으로 판단하는 것을 주 의하여야 한다고 하였다. 따라서, 본 연구에서도 실어증 유형과 상 관없이 전반적인 실어증 환자들을 대상으로 능동 및 피동 문장 산 출 과정의 특징을 알아보고자 하였다.

영어는 주어-동사-목적어(SVO)의 구조로 나타나지만, 한국어는 주어-목적어-동사(SOV) 순으로 나타나는 동사 중심의 언어이다 (Park, 2012). 또한, 한국어는 주어와 같은 문장 구성 성분의 생략이 빈번하게 일어나며(Park, 2013) 영어에는 존재하지 않는 문법적 요 소인 조사가 붙게 된다. 따라서 한국어 실어증 환자들은 영어를 사 용하는 실어증 환자와 능동문과 피동문 산출 과정에서 다른 특성 을 보일 것으로 예상되어 한국어를 사용하는 실어증 환자를 대상 으로 한 능동 및 피동 문장의 산출 과정을 알아볼 필요성이 있다.

국내에서 실어증 환자를 대상으로 능동문과 피동문에 대해 살펴 본 기존의 연구들은 이해에 대한 연구가 대부분이며, 산출에 대한 부분은 매우 부분적으로 보고되어왔다. 또한, 국내에서 시선추적 기를 활용하여 실어증 환자의 문장 산출을 실시간 문장 처리과정 으로 살펴본 연구는 거의 없는 실정이다. 이에 본 연구에서는 Cho 와 Thompson (2010)의 시선추적 실험을 바탕으로 구문 점화 과제 를 제작하여 실어증 환자들이 정상 성인과 비교하여 능동형 문장 과 피동형 문장을 산출할 때 실시간 문장 처리과정에서 어떠한 차 이를 보이는지 알아보고자 한다. 또한 실어증 환자들이 능동형 문 장과 피동형 문장에서 보이는 오반응을 오류 유형별로 분석하여 각 문장 유형별로 나타나는 오류 유형의 비율을 살펴보고자 한다.

즉, 본 연구는 구문 점화 과제에서 정상 성인과 실어증 환자의 능 동 및 피동 문장 산출 과정을 시선추적기를 활용하여 분석해 봄으 로써 실어증 환자의 능동문과 피동문 산출 능력에 대해 알아보고 자하였다.

본 연구의 연구 질문은 다음과 같다.

첫째, 구문 점화 과제에서 능동 및 피동 문장 산출의 정확도에 정 상 성인과 실어증 환자 간 유의한차이가 있는가?

둘째, 구문 점화 과제에서 문장 산출 시 정반응한 문항에 대한 능동 및 피동 문장 산출 반응시간(speech onset latency)에 정상 성 인과 실어증 환자 간 유의한 차이가 있는가?

셋째, 구문 점화 과제에서 문장 유형(능동 vs. 피동)에 따라 실어 증 환자의 오반응에서 나타난 오류 유형별 비율은 어떠한가?
넷째, 구문 점화 과제에서 능동 및 피동 문장 산출 시 정상 성인 (정반응)과 실어증 환자(정반응, 오반응) 간 문장 산출 구간에 따라 관심 영역(행위자, 대상)에 대한 시선고정 횟수에 유의한 차이가 있 는가?

\section{연구방법}

\section{연구대상}

본 연구의 대상자는 한국어를 모국어로 사용하는 정상 성인 10 명과 실어증 환자 9 명이다. 모든 대상자는 실험에 참가하기 전 실험 에 대한 안내를 듣고 동의서에 서명한 후에 실험에 참여하였다. 실 험은 생명윤리위원회의 승인을 받아 진행하였다(IRB No. 2019040043-01). 연구 대상자의 구체적인 선정 기준은 다음과 같다. 실어 증 환자는 (1) 좌뇌 피질 및 피질하 부위의 뇌졸중으로 인해 언어 장 애를 보이는 자, (2) 한국판 웨스턴 실어증 검사-개정판(Korean version - Western Aphasia Battery-Revised, K-WAB-R; Kim \& Na, 2012) 결과, 실어증으로 분류된 자, (3) 발병 이전에 뇌손상 및 기타 신경학적 질환이 없었다고 보고된 자, (4) 연령과 교육수준의 차이 가 수행에 미치는 영향을 최소화하기 위해 75세 이하이며, 학력이 초졸 이상인 자를 대상으로 선정하였다. 정상 성인은 (1) 실어증 환 자 집단과 평균 연령 및 평균 교육년수가 일치하는 자, (2) 한국형 간이정신상태검사(Korean-Mini Mental State Examination, KMMSE; Kang, 2006) 점수가 연령 및 교육년수에 비해 $16 \%$ ile 이상 으로 정상 범위에 해당하는 자(Kang, 2006), (3) 서울신경심리검사 2판(Seoul Neuropsychologic Screening Battery-II, SNSB-II; Kang, Jhang, \& Na, 2012)의 하위검사인 서울구어학습검사(Seoul Verbal Learning Test, SVLT) 점수가 연령 및 교육년수에 비해 $16 \%$ ile 이상 으로 정상 범위에 해당하는 자, (4) 그 외에 언어 및 신경학적 손상, 병력이 보고되지 않은 자를 대상으로 선정하였다. 또한, 정상 성인 과 실어증 환자는 과제 수행을 위해 시력과 청력에 문제가 없는 자 로 선정하였다.

집단 간 연령 및 교육년수에 통계적으로 유의한 차이가 있는지 알아보기 위해 맨-휘트니 검정(Mann-Whitney $U$ test)을 실시하였 다. 그 결과, 두 집단의 연령 및 교육년수는 통계적으로 유의한 차이 가 없었다. 본 연구에 참여한 집단 별 대상자 정보는 Table 1에, 실어

Table 1. Demographic information on participants

\begin{tabular}{lcc}
\hline & Normal $(\mathrm{N}=10)$ & Aphasic $(\mathrm{N}=9)$ \\
\hline Age $(\mathrm{yr})$ & $56.7(5.52)$ & $53.2(11.46)$ \\
Education (yr) & $14.8(1.6)$ & $13.6(3.43)$ \\
\hline
\end{tabular}

Values are presented as mean (SD). 
증 환자에 대한 정보는 Table 2에 제시하였다.

\section{연구과제}

능동형과 피동형의 문장 유형에 따른 문장 산출 능력을 측정하 기 위해 연구자가 Cho와 Thompson (2010)의 시선추적 실험에 사 용된 구문 점화 과제 절차와 Sung 등(2018)에서 실시된 구문 점화 과제를 참고하여 본 실험의 구문 점화 과제를 제작하였다. 구문 점 화 과제는 능동형 15 개, 피동형 15 개로 총 30 개의 점화 문장과 30 개 의 목표 문장으로 구성하였다. 모든 문장은 의미 및 구문적으로 타 당하고 가역적인 문장으로 3 개의 어절로 구성되었다. 점화 문장 자 극의 경우 시각적으로 흰색 바탕에 검정색 글자로 화면 중앙에 제 시되었다. 글자 모양은 맑은 고딕이며, 글자 크기는 44포인트로 설 정되었다. 청각적으로는 점화 문장을 성인 여성이 정상 성인의 말속 도로 녹음하여 들려주었다.

목표 문장 자극의 경우 30 개의 가로 $15 \mathrm{~cm} \times$ 세로 $15 \mathrm{~cm}$ 그림 자 극으로 구성되었다. 실험 문장의 그림 자극은 문장산출검사(Sung, 2015)의 형식을 따라 3 가지 색상(노랑이, 파랑이, 검정이)을 캐릭터 화하여 그림으로 제시하였다. 점화 문장의 경우 목표 문장의 산출 을 촉진시키기 위하여 목표 문장과 비슷하게 2가지 색상(분홍이, 주황이)을 주어로 제시하였다. 점화 문장 자극과 목표 문장 그림 자극은 피험자가 문장을 산출하는데 충분한 시간을 가질 수 있도 록 피험자가 스페이스바를 누르면 넘어가도록 설정하였다. 점화 문
장 자극과 목표 문장 그림 자극 사이에는 $300 \mathrm{~ms}$ 동안 흰색 화면이 제공된 후 응시점(+)이 2,000 ms 동안 제시되었다. 목표 문장 그림 자극은 응시점이 사라짐과 동시에 신호음 $(500 \mathrm{~Hz}, 0.5 \mathrm{~s})$ 과 함께 나 타났다. 구문 점화 과제에서 자극 제시 시 능동형과 피동형의 같은 동사 형태가 5 문항 내에 나오지 않도록 하였으며, 같은 문장 유형이 연속하여 2 번을 초과하여 나오지 않도록 자극을 배열하였다. 구문 점화 과제 자극의 예시는 Table 3과 Figure 1과 같다. 구문 점화 과 제의 점화 문장과 목표 문장 목록은 Appendix 1 에 제시하였다.

\section{연구도구}

문장 산출 과정을 실시간으로 알아보기 위해 시선추적기(Eyetracker)를 사용하였다. 연구에 사용된 시선추적기는 독일 SMI (Senso Motoric Instruments)사의 RED (Remote Eye-tracking Device, sampling rate $250 \mathrm{~Hz}$ ) 방식으로 모니터에 부착된 소형 카메라 가 사람의 눈과 시야를 촬영하여 시선을 측정한다. 시선추적기는 안구의 위치와 움직임을 실시간으로 추적하여 인지과정을 확인할 수 있어 실시간 인지 처리과정을 알아보기 위한 다양한 연구에 사 용되고 있다. 단, 피험자가 머리를 움직이게 될 경우 카메라가 피험 자의 눈과 시야를 추적하는데 어려움이 발생할 수 있으므로 턱고 정대(chin rest)를 활용하여 피험자의 머리를 고정하였다. 또한 카 메라와 적정한 간격을 유지하기 위하여 시선추적기와 대상자의 간 격은 60-70 cm로 유지하였다.

Table 2. Descriptive information of participants with aphasia

\begin{tabular}{lcccccccccc}
\hline ID & Age (yr)/sex & Education (yr) & Years post onset & Aphasia quotient & Fluency & Comprehension & Repetition & Naming & Type \\
\hline P1 & $64 / M$ & 12 & 5 & 80.7 & 6 & 8.35 & 9.2 & 8.8 & Anomic \\
P2 & $54 / M$ & 16 & 7 & 68.3 & 3 & 8.85 & 5.6 & 8.7 & Broca \\
P3 & $45 / M$ & 16 & 8 & 83.2 & 8 & 8.6 & 8.4 & 8.6 & Anomic \\
P4 & $52 / F$ & 16 & 2 & 91.3 & 9 & 8.45 & 9.8 & 9.4 & Anomic \\
P5 & $63 / F$ & 12 & 2 & 90.1 & 9 & 8.35 & 9.8 & 8.9 & Anomic \\
P6 & $69 / M$ & 6 & 24 & 89.8 & 9 & 8.6 & 10 & 8.3 & Anomic \\
P7 & $53 / M$ & 16 & 1 & 90.3 & 9 & 8.95 & 9 & 9.2 & Anomic \\
P8 & 48/M & 12 & 8 & 72.1 & 6 & 7.75 & 5.2 & 9.1 & Conduction \\
P9 & $31 / M$ & 16 & 5 & 58.8 & 4 & 7.9 & 4 & 7.5 & Broca \\
\hline
\end{tabular}

Table 3. An example of syntactic priming task

\begin{tabular}{lll}
\hline Sentence type & \multicolumn{1}{c}{ Prime sentence } & \multicolumn{1}{c}{ Target sentence } \\
\hline Active & The Orange pushes the Pink & The Blue pushes the Yellow \\
& Juhwangi-ka Bunhongi-lul mil-ta & Palangi-ka Nolangi-lul mil-ta \\
& The Orange-NOM The Pink-ACC Push-PRES-ACT & The Blue-NOM The Yellow-ACC Push-PRES-ACT \\
Passive & The Pink is pushed by the Orange & The Blue is pushed by the Yellow \\
& Bunhongi-ka Juhwangi-eykey mili-ta & Palangi-ka Nolangi-eykey mili-ta \\
& The Pink-NOM The Orange-by Push-PRES-PASS & The Blue-NOM The Yellow-by Push-PRES-PASS \\
\hline
\end{tabular}

NOM= nominative case marker; $A C C=$ accusative case marker; PRES = present tense suffix; $A C T=$ active suffix; Pass = passive suffix. 


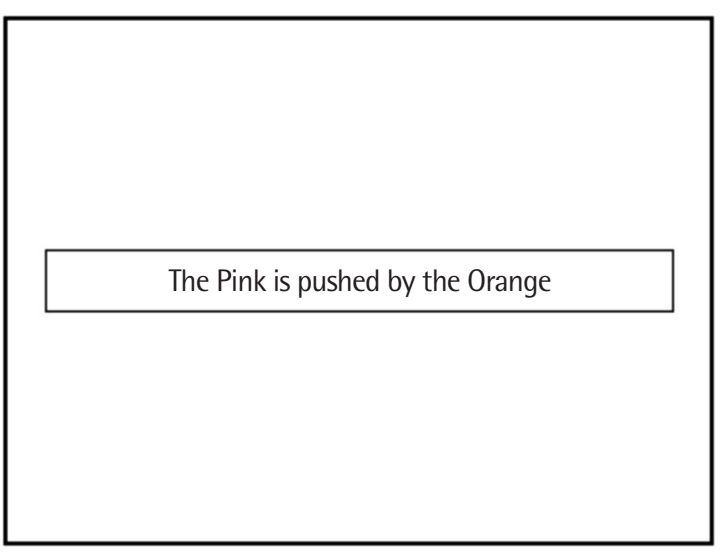

Prime sentence stimuli

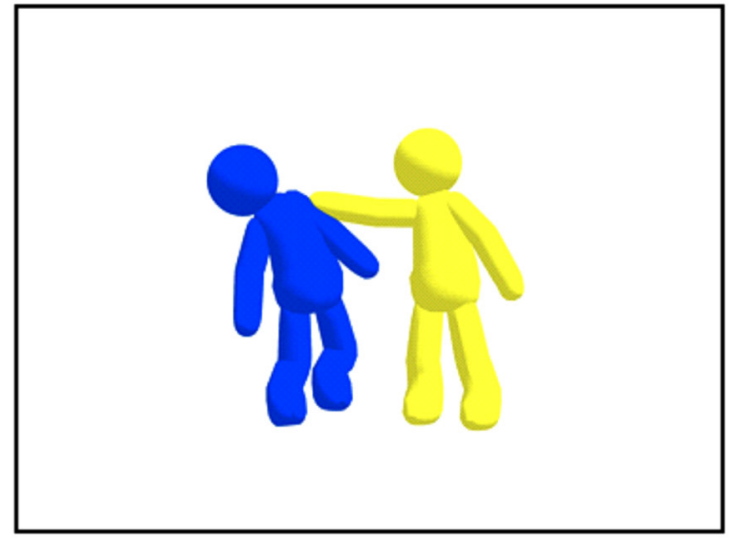

Target sentence stimuli

Figure 1. An example of stimuli for syntactic priming task.

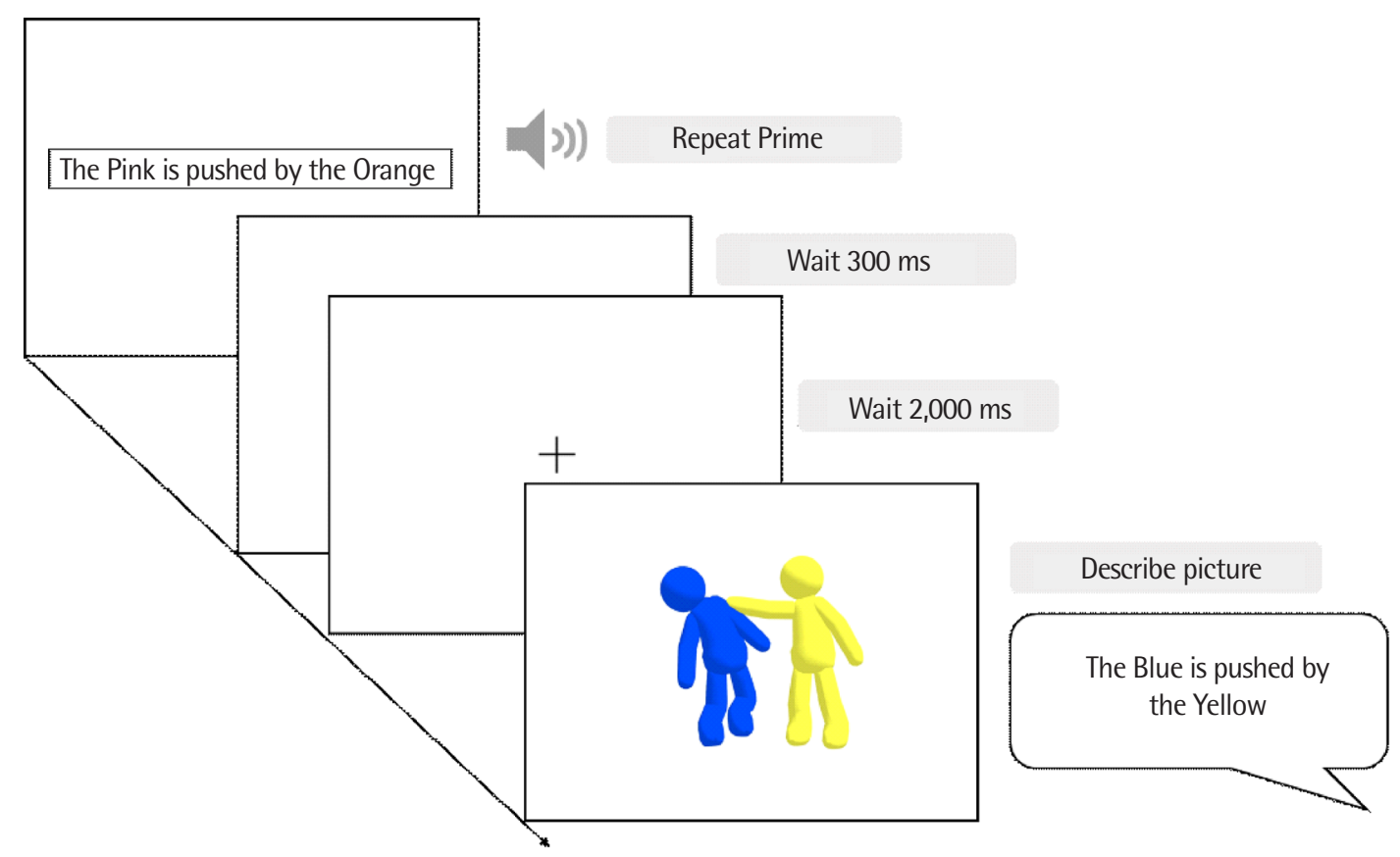

Figure 2. Experimental procedures.

\section{연구절차}

모든 대상자에게 개별적으로 선별 검사를 실시한 후, 연구 참여 자가 충분히 실험에 대해 숙지할 수 있도록 연구자의 개인용 노트 북으로 연습문항을 진행하였다. 먼저, 구문 점화 과제에 사용되는 그림 자극을 보여주며 그림 자극 이해에 어려움이 없는지 확인하였 다. 연습문항을 시작하기 전 대상자에게 "이제부터 연습문항을 풀 어보겠습니다. 말소리와 함께 화면에 문장이 나옵니다. 말소리를 들은 후 말소리를 그대로 따라 말씀해주세요. 따라 말씀하신 후에 스페이스바를 눌러주세요. '삐' 소리와 함께 나타나는 그림을 보시
고 앞에 나온 말소리를 이용하여 적절하게 문장을 만들어 말씀해 주세요. 말소리는 딱 한 번만 들려드리니 집중해서 들어 주시기 바 랍니다. 그럼 시작하겠습니다.”라는 지시문을 들려주었다. 연습문 항은 능동형 점화 문장 조건 2 문항과 피동형 점화 문장 조건 2 문항 으로 제작되었으며, 연습문항에서 대상자가 오반응을 보인 경우 연 구자가 오반응에 대한 피드백을 주었다. 대상자가 연습문항을 통해 실험에 대해 충분히 이해했다고 판단되면 본 실험을 진행하였다.

본 실험은 소음 요인을 배제하기 위해 조용한 장소에서 실시하였 다. 피험자가 모니터 앞에 착석하면 시선의 오차를 줄이기 위하여 
턱받침대에 머리를 고정시키고 사전 보정(calibration) 작업을 실시 하였다. 사전 보정 단계에서 피험자는 검은색 화면에 순차적으로 나타나는 9개의 빨간 목표점을 눈으로 따라가는 과정을 거쳤으며, 동공의 최적의 편차 값인 $0.5^{\circ}$ 이하로 목표점의 주시 결과가 나올 때까지 실시하였다(Holmqvist et al., 2011).

본 실험을 시작하기 전 과제 진행 방법에 대해 다시 간략하게 설 명한 후 실험을 시작하였다. 시선 추적의 정확성을 위해 보정단계 는 실험 과정 중 10 문항 간격으로 실시되었으며, 대상자가 피로감 을 호소할 경우 충분한 휴식시간을 제공하였다. 피험자의 시선고정 은 시선추적기를 사용하여 기록되었으며, 구문 점화 과제에서 피험 자의 발화는 스마트폰(Samsung Galaxy S9)을 사용하여 녹음되었 다. 선별 검사를 포함한 전체 실험 소요 시간은 정상 성인의 경우 약 30 분, 실어증 환자의 경우 약 1 시간 정도 소요되었다. 실험 과정은 Figure 2와같다.

\section{자료분석}

각 피험자의 녹음 파일은 연구자에 의해 전사 및 분석되었다. 목 표 문장에 관해 산출된 간투사와 자가 수정을 포함하여 모든 반응 이 전사되었으며, 한 목표 문장에 대해 한 번 이상의 시도가 이루어 진 경우 가장 정반응에 가까운 반응이 분석에 사용되었다.

정반응의 경우 Cho와 Thompson (2010)의 연구를 참고하여 정 의되었다. 먼저, 정반응은 점화 문장에 맞게 적절하게 산출된 능동 형 문장과 피동형 문장으로 정의되었다. 능동형 점화 문장의 경우, 점화 문장의 통사적 구조에 맞게 '노랑이가 파랑이를 밀다'와 같이 행위자(Noun Phrase, NP1)-대상(NP2)-능동형 동사(V) 순으로 구 성되며, 주격 조사 '-가'와 목적격 조사 '-을/를'이 모두 적절하게 산 출되었을 때 정반응으로 간주되었다. 피동형 점화 문장의 경우, 점 화 문장의 통사적 구조에 맞게 '파랑이가 노랑이에게 밀리다'와 같 이 대상(NP1)-행위자(NP2)-피동형 동사(V) 순으로 구성되면서, 주격 조사'-가'와 여격 조사'-에게'가 모두 적절하게 산출되었을 때 정반응으로 간주되었다. 행위자와 대상이 되는 '노랑이, 파랑이, 검 정이'의 경우 대상자가 의미가 비슷한 명사 형태(파란 거, 검정색 등)를 산출한 경우에도 적절하게 산출한 것으로 보았다. 또한, 피동 문에서 여격조사 '-에게' 대신 '-한테'를 붙여 산출한 경우에도 적절 하게 산출한 것으로 처리하였다.

오반응에 따른 오류 유형은 Mack 등(2017)의 연구를 참고하여 다음과 같이 정의되었다. 의미역 할당은 적절하게 이루어졌으나 생 략이나 대치 등으로 인하여 조사의 사용이 적절치 못한 경우 조사 오류(Grammatical morphology errors)로 간주되었다. 문법적 형태 에는 오류가 없으나 의미역 할당이 반대로 이루어졌을 때 의미역
전환 오류(Role reversals errors)로 간주되었다. 능동형 점화 문장 조건에서 같은 의미의 피동형 문장을 산출하거나 피동형 점화 문 장 조건에서 같은 의미의 능동형 문장을 산출하는 경우 문장 유형 전환 오류(sentence type reversals errors)로 간주되었다. 위와 같은 기준을 충족하지 못하는 다른 오류의 경우(불완전하게 산출된 문 장 등)는 기타 오류로 분류되었다. 오류 유형과 그에 따른 예시는 Appendix 2에 제시하였다. 이때 정반응은 1점, 오반응은 0 점으로 처리하여 능동형 문장 15 개와 피동형 문장 15 개의 각 항목에서의 수행을 측정하였으며 이를 백분율로 변환하여 분석하였다. 실어증 환자의 오류 유형은 각 문장 유형별로 전체 오류의 개수를 구한 뒤, 각 오류 유형의 개수를 전체 오류 개수로 나누고 100 을 곱해 백분 율을 계산하였다.

문장 산출 반응시간(speech onset latency)은 Praat software version 6.0.4.0 (Boersma \& Weenink, 2018)을 이용하여 각 어절마다 측정되었다(NP1-NP2-V-End). 목표 문장의 그림 자극이 제시된 시 점부터 각 어절이 개시된 시간이 측정되었으며 어절 내에서 자가 수정이 있었을 경우, 목표 형태소와 음성적으로 비슷한 첫 번째 시 도가측정되었다.

시선 추적 분석은 관심 영역(areas of interest, $\mathrm{AOI}$ )에 기반하여 처리되었다. 관심 영역(AOI)은 그림 자극에서 관심 대상의 장소에 의해 정의된다. 목표 문장의 그림 자극에서 '행위자'와 '대상'은 같 은 크기의 두 개의 사각형 구역에 포함되었다. 시선고정은 지정된 $\mathrm{AOI}$ 구역을 $100 \mathrm{~ms}$ 동안 변함없이 응시했을 때 수집되었다. 시선고 정 횟수는 어절에 따라 구분된 문장 산출 구간(Before Onset, NP1, $\mathrm{NP} 2, \mathrm{~V}$-End) 동안 시선고정이 일어난 횟수가 계산되었다. 이때 시 선추적 비율(tracking ratio)이 70\% 미만인 데이터는 분석에서 제 외하였다. 전체 대상자 중 실어증 환자에서 2 명 $(\mathrm{P} 2, \mathrm{P} 9)$ 의 시선추적 비율이 $70 \%$ 미만으로 나타나 시선추적 측정치 분석에서 제외되었 다. 또한 분석 구간 내에 아무 반응이 기록되지 않은 값은 분석에서 제외하였다. 시선 추적 데이터는 SMI사의 'Be Gaze 3.7' 프로그램 을 이용하여 분석되었다.

\section{통계적 처리}

본 연구 자료의 통계적 처리는 IBM SPSS statistics version 25.0 을 사용하여 분석하였다. 먼저 집단 간 구문 점화 과제에서 집단 간 구문 점화 과제의 문장 유형별 정반응률과 문장 산출 반응시간 (speech onset latency)의 차이를 알아보기 위해 맨-휘트니 $U$ 검정 (Mann-Whitney U Test)을 실시하였다. 또한 문장 유형에 따라 정 상 성인 및 실어증 환자 집단 내의 문장 산출 정반응률과 문장 산 출 반응시간에 유의한 차이가 있는지 알아보기 위해 윌콕슨 부호- 
순위 검증(Wilcoxon Signed-Rank Test)을 실시하였다. 마지막으로 구문 점화 과제에서 능동 및 피동 문장 산출 시 정상 성인(정반응) 과 실어증 환자(정반응, 오반응) 간 문장 산출 구간에 따라 관심 영 역 '행위자'와 '대상'에 대한 시선고정 횟수에 유의한 차이가 있는 지 알아보기 위해 윌콕슨 부호-순위 검증(Wilcoxon Signed-Rank Test)을 실시하였다.

\section{연구결과}

\section{능동 및 피동 문장 산출 정확도}

두 집단 간 구문 점화 과제에서 능동 및 피동 문장 산출 정확도에 대해 비교한 결과는 Table 4 와 같다. 구문 점화 과제에서 능동 및 피 동 문장 산출 정확도에 대한 정반응율의 평균과 표준편차는 Appendix 3 에 제시하였다.

\section{집단 간 비교(Mann-Whitney U Test)}

구문 점화 과제에서 능동 및 피동 문장 산출 정확도에 두 집단 간 차이가 유의한지 분석한 결과, 능동문에서 실어증 환자의 정반응 률이 정상 성인의 정반응률에 비해 통계적으로 유의하게 낮았다 $(Z=-3.98, p<.001)$. 또한, 피동문에서도 실어증 환자의 정반응률 이 정상 성인의 정반응률에 비해 통계적으로 유의하게 낮은 것으 로 나타났다 $(Z=-3.32, p<.001)$.

Table 4. Comparison of accuracy (\%) between two groups

\begin{tabular}{lccccc}
\hline \multirow{2}{*}{ Group } & \multicolumn{2}{c}{ Active } & & \multicolumn{2}{c}{ Passive } \\
\cline { 2 - 3 } \cline { 6 - 7 } & Median & IOR & & Median & IOR \\
\hline Normal $(\mathrm{N}=10)$ & 100 & 0 & & 100 & 0 \\
Aphasic $(\mathrm{N}=9)$ & 67 & 66.5 & & 7 & 76.5 \\
\hline
\end{tabular}

$\mathrm{IQR}=$ interquartile range.

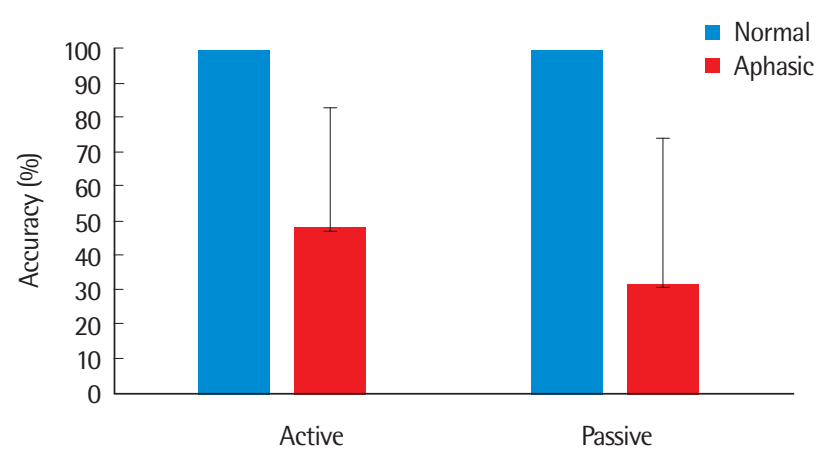

Figure 3. Accuracy of syntactic priming task for each sentence type (Error $\mathrm{Bar}=\mathrm{SD})$.

\section{집단 내 비교(Wilcoxon Signed-Rank Test)}

문장 유형에 따라 실어증 환자의 정반응률에 차이가 있는지 알 아본 결과, 실어증 환자의 능동문 정반응률과 피동문 정반응률 사 이에 유의한 차이가 없는 것으로 나타났다 $(Z=-1.54, p=0.123)$. 정 상 성인의 경우 능동 및 피동 문장 산출에서 모두 정반응을 보여 문장 유형에 따른 정반응률의 차이에 대한 검정을 실시하지 않았 다. 구문 점화 과제에서 집단에 따른 문장 유형별 산출 정확도 도표 는 Figure 3과 같다.

\section{능동 및 피동 문장 산출 반응시간}

구문 점화 과제에서 능동 및 피동 문장을 적절하게 산출하는데 걸린 시간의 집단 간 차이와 집단 내 차이를 알아보았다. 문장 산출 반응시간(Speech Onset Latency)에서 $\pm 2 \mathrm{SD}$ 범위에 벗어나는 데 이터를 이상값(outlier)으로 처리하여 분석에서 제외하였다. 또한, 각 능동 및 피동 문장 점화 조건에서 정반응을 보이지 않은 실어증 환자는 분석에서 제외되었다. 최종적으로 능동문에서 7 명 $(\mathrm{P} 1, \mathrm{P} 3$, $\mathrm{P} 4, \mathrm{P} 5, \mathrm{P} 6, \mathrm{P} 7, \mathrm{P} 8)$, 피동문에서 5명( $\mathrm{P} 3, \mathrm{P} 4, \mathrm{P} 5, \mathrm{P} 6, \mathrm{P} 7)$ 의 결과가 분 석에 사용되었다. 두 집단 간 구문 점화 과제에서 능동 및 피동 문 장 산출 반응시간에 대해 비교한 결과는 Table 5 와 같다. 구문 점화 과제에서 능동 및 피동 문장 산출 반응시간에 대한 평균과 표준편 차는 Appendix 4에 제시하였다.

Table 5. Comparison of speech onset latency (sec) between two groups

\begin{tabular}{lrrrrr}
\hline \multirow{2}{*}{ Group } & \multicolumn{2}{c}{ Active } & & \multicolumn{2}{c}{ Passive } \\
\cline { 2 - 3 } \cline { 6 - 6 } & Median & \multicolumn{1}{c}{ IQR } & & Median & \multicolumn{1}{c}{ IQR } \\
\hline Normal $(\mathrm{N}=10)$ & $1,278.16$ & 398.28 & & $1,195.61$ & 258.28 \\
Aphasic $(\mathrm{N}=9)$ & $3,299.00$ & $2,061.50$ & & $3,358.43$ & $1,721.60$ \\
\hline
\end{tabular}

$\mathrm{IQR}=$ interquartile range.

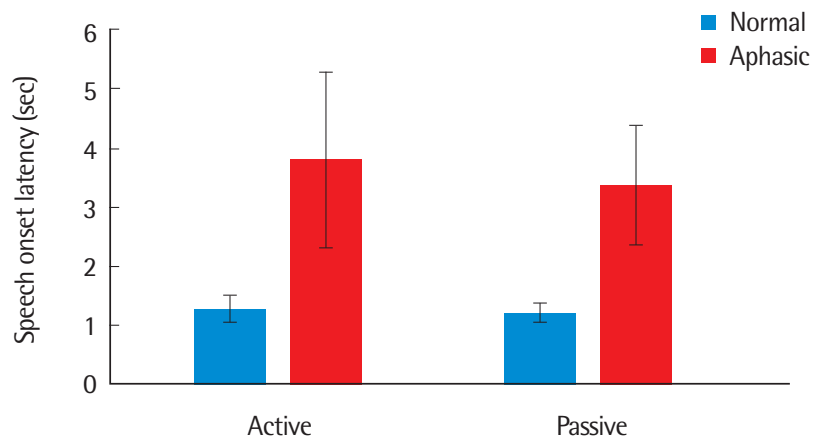

Figure 4. Speech onset latency of syntactic priming task for each sentence type (Error Bar=SD). 


\section{집단 간 비교(Mann-Whitney U Test)}

능동문에서 실어증 환자의 문장 산출 반응시간과 정상 성인의 문장 산출 반응시간 사이에 통계적으로 유의한 차이가 나타났다 $(Z=-3.42, p<.001)$. 또한, 피동문에서도 실어증 환자의 문장 산출 반응시간이 정상 성인의 문장 산출 반응시간과 통계적으로 유의한 차이를 보이는 것으로 나타났다 $(Z=-3.06, p<.01)$.

\section{집단 내 비교(Wilcoxon Signed-Rank Test)}

문장 유형에 따라 집단 내 문장 산출 반응시간에 차이가 있는지 살펴본 결과, 정상 성인의 경우 능동문과 피동문 산출 반응시간에 유의한 차이가 없는 것으로 나타났다 $(Z=-.26, p=0.799)$. 또한, 실 어증 환자에서도 문장 유형에 따른 문장 산출 반응시간에 유의한 차이가 나타나지 않았다 $(Z=-1.75, p=.08)$. 구문 점화 과제에서 집 단에 따른 능동 및 피동 문장 산출 반응시간에 대한 도표는 Figure 4 와같다.

\section{실어증 집단의 문장 유형에 따른 오류 유형}

실어증 집단에서 구문 점화 과제에서 능동 및 피동 문장 산출의
오류 유형을 분석하였다. 능동형 문장에서 오반응은 총 70 개, 피동 형 문장에서 오반응은 총 92 개로 나타났다. 각 문장 유형별로 오반 응의 오류 유형을 분석한 결과는 Table 6과 Figure 5에 제시하였다. 능동형 문장에서 오류 유형별 비율을 보면 기타 오류가 $61.43 \%$ 로 가장 많았으며, 조사 오류(20.00\%), 문장 유형 전환 오류(11.43\%), 의미역 전환 오류(7.14\%) 순으로 나타났다. 피동형 문장에서 오류 유형별 비율은 기타 오류가 $57.61 \%$ 로 가장 많았으며, 문장 유형 전 환 오류(25.00\%), 의미역 전환 오류(13.04\%), 조사 오류(4.35\%) 순 으로 나타났다.

기타 오류에 대한 추가 분석을 실시한 결과, 능동형 점화 문장 조 건에서 나타난 기타 오류는 불완전하게 산출된 문장(44.19\%)-그 외 오류(27.91\%)-복합오류(25.58\%)-무반응(2.33\%) 순으로 나타났 다. 피동형 점화 문장 조건에서는 복합오류(60.38\%)-불완전하게 산 출된 문장(30.19\%)-그 외 오류(9.43\%) 순으로 나타났으며 무반응 은 없었다.

\section{문장 산출 구간에 따른 시선고정 횟수}

구문 점화 과제에서 정상 성인(정반응)과 실어증 환자의 정반응

Table 6. Rates of error types for each sentence type in aphasic patients

\begin{tabular}{|c|c|c|c|}
\hline Error type & Definition & Active & Passive \\
\hline Grammatical morphology & Errors in grammatical morphology & $14(20.00)$ & $4(4.35)$ \\
\hline Role reversals & Reversals of Agent and Theme & $5(7.14)$ & $12(13.04)$ \\
\hline Sentence type reversals & Active for passive or passive for active & $8(11.43)$ & $23(25.00)$ \\
\hline Others & Incomplete utterance; no response; two or more of the above error types & $43(61.43)$ & $53(57.61)$ \\
\hline Total number of errors & & 70 & 92 \\
\hline
\end{tabular}

Values are presented as number of errors (percentage of total number of errors).
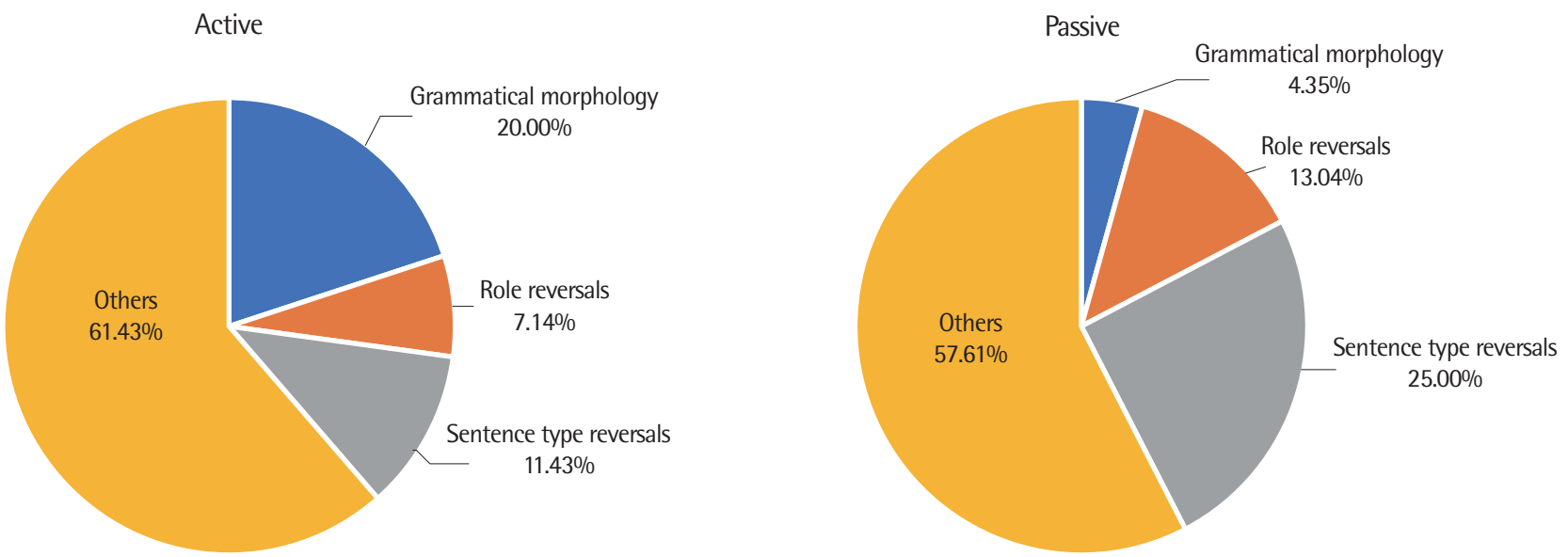

Figure 5. Analyses of error ratio for each sentence type in aphasic group. 
Table 7. Comparison of AOI (Agent, Theme) from each of the speech region in active prime sentence condition

\begin{tabular}{|c|c|c|c|c|c|c|c|c|}
\hline \multirow{2}{*}{$\begin{array}{l}\text { Speech region } \\
\mathrm{AOI}\end{array}$} & \multicolumn{2}{|c|}{ Before Onset } & \multicolumn{2}{|c|}{ NP1 } & \multicolumn{2}{|c|}{ NP2 } & \multicolumn{2}{|c|}{ V-End } \\
\hline & Agent & Theme & Agent & Theme & Agent & Theme & Agent & Theme \\
\hline Normal adults $(\mathrm{N}=10)$ & $2.27(1.02)$ & $1.73(1.12)$ & $0.33(0.37)$ & $1.70(0.43)$ & $0.40(0.33)$ & $1.27(0.82)$ & $0.50(0.30)$ & $0.90(1.08)$ \\
\hline Aphasia correct ( $\mathrm{N}=7)$ & $5.00(0.77)$ & $3.18(3.11)$ & $0.82(0.70)$ & 3.29 (3.03) & $1.09(1.00)$ & $2.57(2.05)$ & $0.50(0.53)$ & $0.64(0.70)$ \\
\hline Aphasia incorrect ( $N=7)$ & $4.50(3.00)$ & $3.80(3.30)$ & $1.75(2.56)$ & $3.00(4.20)$ & $0.80(1.50)$ & $1.90(2.20)$ & $0.60(0.80)$ & $1.00(0.70)$ \\
\hline
\end{tabular}

Values are presented as median (Interquartile range)

$\mathrm{NP}=$ Noun Phrase; V-End=Verb-End; $\mathrm{AOI}=$ areas of interest.
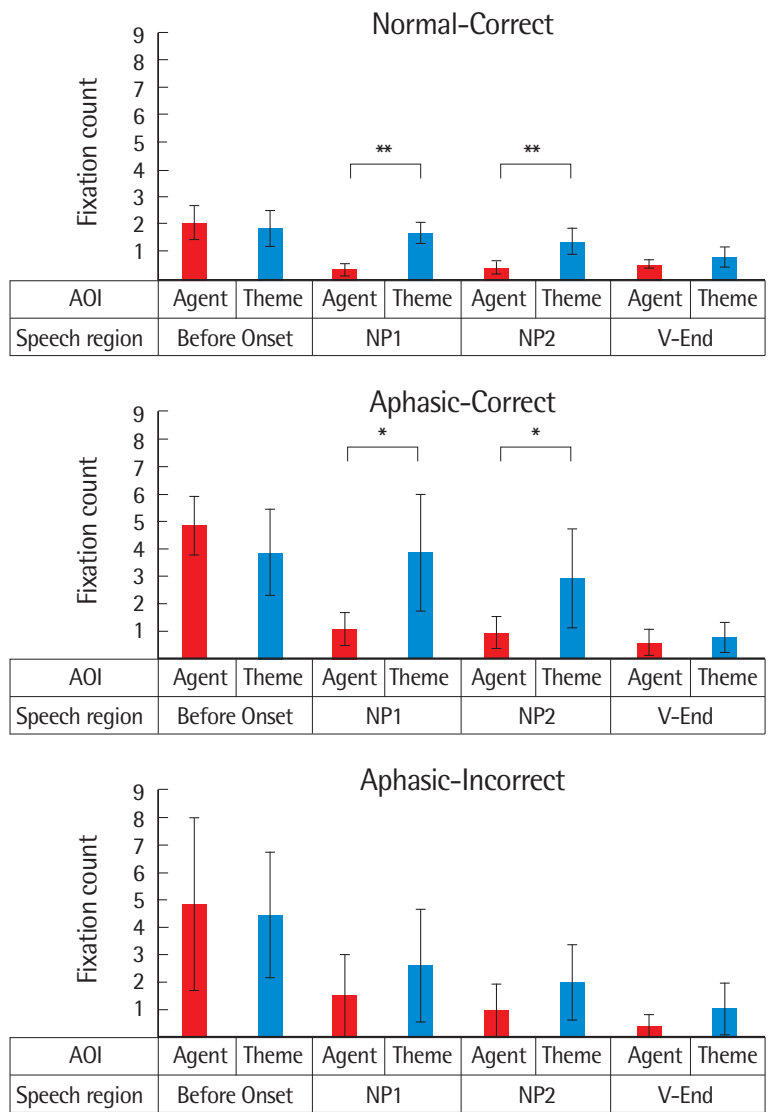

Figure 6. Fixation counts of $\mathrm{AOI}$ (Agent, Theme) from each speech region among groups in active prime condition (Error Bar $=$ SD).

$\mathrm{NP}=$ Noun Phrase; $\mathrm{V}$-End = Verb-End; $\mathrm{AOI}=$ areas of interest. ${ }^{*} p<.05,{ }^{* *} p<.01$.

및 오반응 간 문장 산출 구간(Before Onset, NP1, NP2, V-End)에 따라 구간별로 관심 영역 '행위자'와 '대상'을 본 시선고정 횟수를 분석하였다. 이때 오반응의 경우, 불완전하게 산출된 문장을 제외 하고 NP1-NP2-V 구조로 산출된 오반응만 분석에 사용하였다. 시 선추적 측정치 분석이 가능했던 7명의 실어증 환자들 가운데 피동 형 문장 점화 조건에서 2 명의 실어증 환자(P6, P7)가 모든 문항에서 정반응을 보이고, 2 명의 실어증 환자( $\mathrm{P1}, \mathrm{P} 9)$ 가 모든 문항에서 오반 응을 보여 피동문의 정반응과 오반응 분석에서 각각 실어증 환자 5
명의 결과가 사용되었다. 문장 산출 구간(Before Onset, NP1, NP2, V-End)에 따라 구간별 관심 영역(행위자, 대상)을 본 시선고정 횟 수의 평균과 표준편차는 Appendix 5에 제시하였다.

\section{능동형 점화 문장}

능동형 점화 문장 조건에서 문장 산출 구간별 관심 영역(행위자, 대상)의 시선고정 횟수에 대해 비교한 결과는 Table 7과 같다. 능동 형 점화 문장 조건에서 정상 성인은 NP1과 NP2 구간에서 관심 영 역(행위자, 대상) 간 시선고정 횟수의 유의한 차이가 나타났다(NP1: $Z=-2.81, p<.01 ; \mathrm{NP} 2: Z=-2.81, p<.01)$. 나머지 구간에서는 유의 한 차이를 보이지 않았다(Before Onset: $Z=-1.02, p>.05$; V-End: $Z=-1.72, p>.05)$.

실어증 환자의 정반응에서도 정상 성인과 비슷하게 NP1 구간과 $\mathrm{NP2}$ 구간에서 관심 영역(행위자, 대상) 간 시선고정 횟수에서 유의 한 차이가 나타났으며(NP1: $Z=-2.37, p<.05 ; \mathrm{NP2}: Z=-2.37, p<.05)$, 나머지 구간에서는 유의한 차이를 보이지 않았다(Before Onset: $Z=-1.19, p>.05$; V-End: $Z=-.51, p>.05$ ). 실어증 환자의 오반응에 서는 모든 구간에서 관심 영역(행위자, 대상) 간 시선고정 횟수에 유의한 차이가 나타나지 않았다(Before Onset: $Z=.00, p>.05$; NP1: $Z=-.74, p>.05$; NP2: $Z=-1.57, p>.05$; V-End: $Z=-1.36, p>.05)$. 결 과는 Figure 6에 제시하였다.

\section{피동형 점화 문장}

피동형 점화 문장 조건에서 문장 산출 구간별 관심 영역(행위자, 대상)의 시선고정 횟수에 대해 비교한 결과는 Table 8 과 같다. 피동 형 점화 문장 조건에서 문장 산출 구간별 관심 영역(행위자, 대상) 의 시선고정 횟수에 차이가 있는지에 대해 알아보았다. 피동형 점 화 문장 조건에서 정상 성인은 Before Onset 구간과 V-End 구간에 서 관심 영역(행위자, 대상) 간 시선고정 횟수에 유의한 차이를 보였 다(Before Onset: $Z=-2.81, p<.01 ; \mathrm{V}$-End: $Z=-2.50, p<.05$ ). 나머지 구간에서는 유의한 차이가 나타나지 않았다(NP1: $Z=-1.54, p>.05$; $\mathrm{NP2}: Z=-1.43, p>.05)$. 
Mi Kyung Shin, et al. • Active and Passive Sentence Production in Aphasia Using Eye-tracking

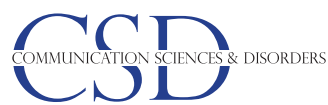

Table 8. Comparison of AOI (Agent, Theme) from each of the speech region in passive prime sentence condition

\begin{tabular}{|c|c|c|c|c|c|c|c|c|}
\hline \multirow{2}{*}{$\begin{array}{l}\text { Speech region } \\
\mathrm{AOI}\end{array}$} & \multicolumn{2}{|c|}{ Before Onset } & \multicolumn{2}{|c|}{ NP1 } & \multicolumn{2}{|c|}{ NP2 } & \multicolumn{2}{|c|}{ V-End } \\
\hline & Agent & Theme & Agent & Theme & Agent & Theme & Agent & Theme \\
\hline Normal $(\mathrm{N}=10)$ & $0.93(0.77)$ & $2.50(0.97)$ & $1.30(0.97)$ & $0.87(0.88)$ & $0.93(0.67)$ & $1.33(0.62)$ & $0.57(0.47)$ & $0.87(0.82)$ \\
\hline Aphasia correct $(\mathrm{N}=5)$ & $2.25(2.02)$ & $5.80(2.12)$ & $2.00(2.12)$ & $1.50(2.58)$ & $1.25(0.87)$ & $1.67(1.42)$ & $0.25(0.51)$ & $0.80(0.98)$ \\
\hline Aphasia incorrect ( $N=5)$ & $5.00(1.92)$ & $3.29(2.02)$ & $0.71(2.45)$ & $3.73(4.21)$ & $1.29(1.54)$ & $1.87(3.44)$ & $0.47(1.33)$ & $1.14(1.19)$ \\
\hline
\end{tabular}

Values are presented as median (Interquartile range).

$\mathrm{NP}=$ Noun Phrase; $\mathrm{V}$-End=Verb-End; $\mathrm{AOI}=$ areas of interest.
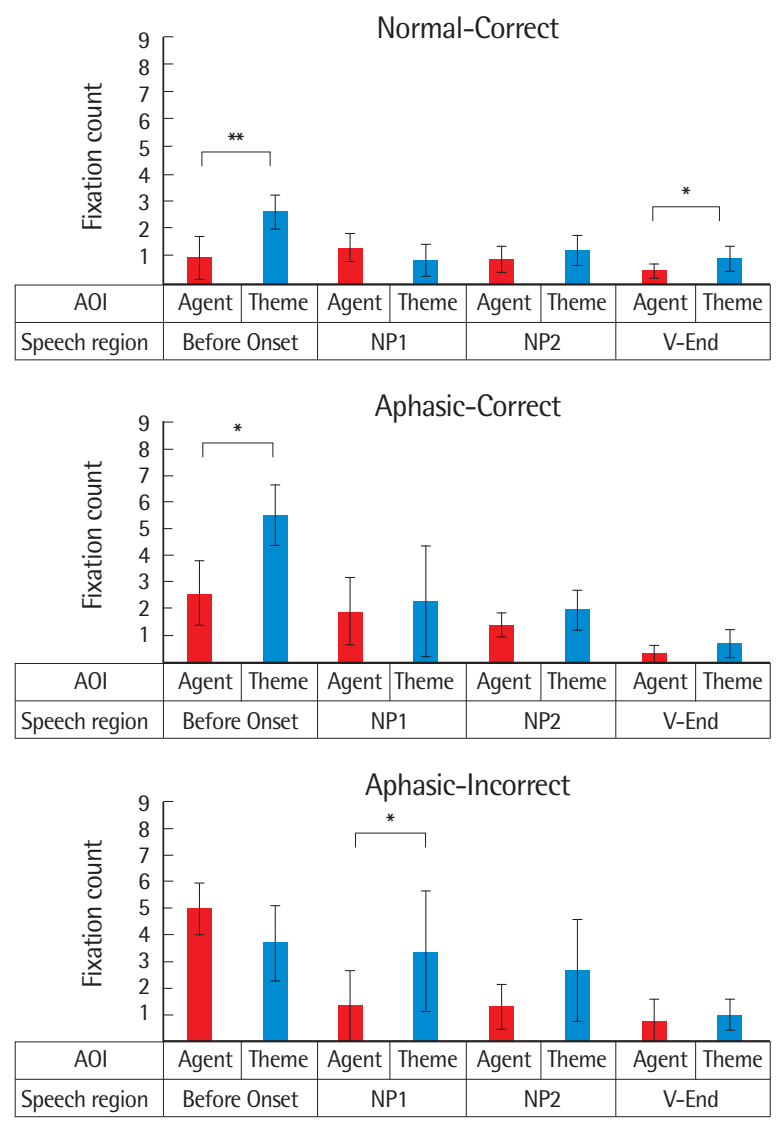

Figure 7. Fixations count of $\mathrm{AOI}$ (Agent, Theme) from each speech region among groups in passive prime condition (Error Bar $=\mathrm{SD})$. $\mathrm{NP}=$ Noun Phrase; V-End = Verb-End; $\mathrm{AOI}=$ areas of interest. ${ }^{*} p<.05,{ }^{* *} p<.01$.

실어증 환자의 정반응에서는 Before Onset 구간에서만 관심 영 역(행위자, 대상) 간 시선고정 횟수에서 유의한 차이가 나타났다 $(Z=-2.02, p<.05)$. 나머지 구간에서는 유의한 차이를 보이지 않았 다(NP1: $Z=-.41, p>.05 ; \mathrm{NP} 2: Z=-.67, p>.05$; V-End: $Z=-1.48$, $p>.05)$. 실어증 환자의 오반응에서는 NP1 구간에서 관심 영역(행 위자, 대상 $)$ 간 시선고정 횟수에 유의한 차이를 보였다 $(Z=-2.02$, $p<.05$ ). 나머지 구간에서는 유의한 차이를 보이지 않았다(Before Onset: $Z=-1.21, p>.05$; NP2: $Z=-1.48, p>.05$; V-End: $Z=-.73$, p>.05). 결과는 Figure 7에 제시하였다.

\section{논의 및 결론}

본 연구는 정상 성인과 실어증 환자를 대상으로 동일한 구문구 조를 먼저 제시하는 구문 점화 과제를 이용하여 능동 및 피동 문장 산출 능력을 알아보고자 하였다. 능동 및 피동 문장 점화 조건에서 실어증 환자가 정상 성인보다 정반응률이 낮으며 문장 산출 반응 시간이 더 오래 걸리는 것으로 나타났다. 이는 실어증 환자가 문장 을 산출하는 데 있어 어려움을 보인다는 선행연구와 일치하는 결 과이다(Burchert et al., 2008; Choi, 2012; Faroqi-Shah \& Thompson, 2003; Sohn, 2004; Thompson et al., 2013; Thompson \& Lee, 2009). 그러나 정상 성인과 실어증 환자 모두 정반응률과 문장 산 출 반응시간에 대한 문장 유형에 따른 집단 내 차이는 유의하지 않 은 것으로 나타났다. 따라서 본 연구에서 실어증 환자는 능동문 산 출과 피동문 산출에서 모두 어려움을 보인 것으로 나타났다.

실어증 환자의 능동 및 피동 점화 문장 조건에서 오류 유형의 비 율을 살펴보았다. 그 결과, 오류 유형의 비율은 능동형 점화 문장 조 건에서 기타(61.43\%)-조사(20.00\%)-문장 유형 전환(11.43\%)-의미 역 전환(7.14\%) 오류 순으로 나타났다. 피동형 점화 문장 조건에서 는 기타(57.61\%)-문장 유형 전환(25.00\%)-의미역 전환(13.04\%)-조 사(4.35\%) 오류 순으로 나타났다. 능동문과 피동문에서 모두 기타 유형이 가장 높은 비율을 차지하여 능동문과 피동문에서 다양한 영역에서의 결함을 보이는 것으로 나타났다. 이러한 결과는 실어증 환자의 문장 산출에 대한 결함이 특정 영역에 대한 결함으로 이해 되어서는 안 된다는 것을 시사한다. 또한, 능동형 및 피동형 점화 문 장 조건에 따라 각 오류 유형이 차지하는 비율이 다른 것으로 나타 나 능동 및 피동 문장 산출에서 실어증 환자가 주로 보이는 결함이 다른 것으로 나타났다.

시선추적 분석 결과, 능동형 점화 문장 조건에서 정상 성인, 실어 증 환자의 정반응과 오반응 모두 Before Onset 구간에서는 관심 영 역(행위자, 대상) 간 시선고정 횟수에 유의한 차이가 나지 않아 문 
장을 산출하기 전에 '행위자'와 '대상'을 비슷한 수준으로 본 것으 로 보인다. 이를 통해 정상 성인과 실어증 환자 모두 능동문을 산출 하기 전에 '행위자'와 '대상'을 확인하고 주어로 '행위자'를 선택하 는데 큰 노력을 들이지 않음을 유추해볼 수 있다. 한국어는 동사 중 심의 언어로 상대적으로 덜 중요하게 여겨지는 주어의 생략이 빈번 하게 나타나는 특성이 있다(Park, 2013). 한국어는 비교적 어순이 자유롭고, 상황 의존적으로 문장을 산출하기 때문에 반드시 주어 가 있을 필요가 없는 경우 주어를 생략하는 것이 더 일반적이다 (Son, 2001). 이처럼 한국어 사용자는 주어에 대한 처리가 자동적 으로 일어나기 때문에 일반적으로 주어의 위치에 오는 '행위자' 의 미역이 주어에 위치하는 능동문에서 '행위자'와 '대상' 중 '행위자' 의미역을 주어로 선택하는데 비교적 적은 인지적 용량을 사용하는 것으로 보인다.

말 산출을 하기 시작하는 NP1 구간과 NP2 구간에서는 정상 성 인과 실어증 환자의 정반응에서 관심 영역(행위자, 대상)에 대한 시 선고정 횟수에 유의한 차이가 나타나 문장의 주어와 목적어를 산 출하는 동안, 주어인 '행위자'에 비해 목적어로 오는 '대상'을 유의 하게 더 많이 보고 있던 것으로 나타났다. 실어증 환자의 오반응에 서는 NP1 구간과 NP2 구간에서 관심 영역(행위자, 대상)에 대한 시 선고정 횟수에 유의한 차이가 나타나지 않아 적절한 문장 산출에 실패한 것으로 볼수 있다.

마지막으로 V-End 구간에서 정상 성인과 실어증 환자 모두 관심 영역(행위자, 대상)에 대한 시선고정 횟수에 유의한 차이를 보이지 않아 동사 위치에 이르러서는 다시 ‘행위자'와 ‘대상'을 비슷하게 본 것으로 보인다.

피동문에서 정상 성인과 실어증 정반응의 경우 Before Onset 구 간에서 관심 영역(행위자, 대상)에 대한 시선고정 횟수에 유의한 차 이를 보여 문장을 산출하기 전에 '행위자'와 ‘대상'을 비슷하게 보았 던 능동문과는 다르게 문장의 주어가 되는 '대상'을 '행위자'보다 유의하게 더 많이 보고 있던 것으로 나타났다. 능동문에서는 일반 적으로 주어 자리에 위치하는 '행위자'가 주어의 위치에 오기 때문 에 인지적 처리가 비교적 간단하였으나, 피동문에서는 일반적으로 '목적어'의 위치에 오는 '대상'이 주어 자리에 위치하기 때문에 인지 적인 처리에 더 많은 부담이 일어나 문장을 산출하기 전에 '행위자' 보다 '주어'를 더 오랫동안 응시했던 것으로 보인다. Before Onset 구 간에서 실어증 오반응에서는 관심 영역(행위자, 대상) 간 시선고정 횟수의 유의한 차이를 보이지 않아 적절한 문장 산출에 실패한 것 으로 보인다.

말 산출을 하기 시작하는 NP1 구간과 NP2 구간에서 정상 성인 과 실어증 정반응의 경우 관심 영역(행위자, 대상)에 대한 시선고정
횟수의 유의한 차이가 나타나지 않아 ‘행위자'와 ‘대상’을 비슷하게 보고 있던 것으로 볼 수 있다. 문장을 산출하기 전에 주어가 되는 '대상'을 확인하면 목적어는 저절로 결정이 되기 때문에(Park, 2012), 말 산출을 하는 과정에서는 '대상' 또는 '행위자'를 유의하게 더 많 이 보지 않은 것으로 보인다. 반면에, 실어증 환자가 오반응을 한 경 우에는 NP1 구간에서 '행위자'에 비해 '대상'을 더 많이 응시한 것 으로 나타났는데 이러한 결과는 피동문에서 나타난 문장 유형 전 환 오류(25.00\%)와 의미역 전환 오류(13.04\%) 등으로 미루어 보았 을 때 의미역 할당이 반대로 이루어졌을 가능성과, 실어증 환자의 처리과정의 효율성 저하로 인해 처리과정이 지연되어 Before Onset 구간이 아닌 NP1 구간에서 유의한 차이가 나타났을 가능성이 있 다. 이러한 피동문에서의 지연된 처리과정은 말 산출을 하기 전에 계획이 제대로 이루어지지 않았음을 나타내며 실어증 환자들이 피 동문 산출을 계획하는 단계에서부터 어려움을 겪는다는 것을 보 여준다.

마지막으로 V-End 구간에서 정상 성인에서만 관심 영역(행위자, 대상)에 대한 시선고정 횟수의 유의한 차이가 나타나 '대상'을 '행 위자'보다 더 많이 응시한 것으로 나타났다. 정상 성인의 경우 구문 구조가 복잡한 피동문에서 동사 위치에 이르러 자동적으로 통사 구조를 한번 더 확인하는 과정을 거친 것으로 보이며 이러한 결과 는 Kim (1995)의 한국어 통사 처리 과정에서 마지막 동사 위치에서 이미 이루어진 구조를 확증하거나 수정할 것이라는 가설을 지지한 다. 그러나 실어증 환자에서는 이러한 재확인과정이 나타나지 않았 다. 따라서 피동문 산출 후 재확인을 하는 과정을 거치도록 단어 카 드를 사용하여 문장을 만들어보고, 제대로 문장을 만들었는지 재 확인하는 과정을 거치다가 점차 익숙해지면 그림을 보고 말로 산 출한 후 재확인을 하도록 하여 문장구조에 대한 재확인 과정을 촉 진시키는 전략이 필요할 것이다.

Mack 등(2017)의 연구에서는 전체 문항과 정반응만을 시선추적 분석에 포함하였으나, 본 연구에서는 정반응보다 오반응이 많아 오 반응을 분석할 수 있는 자료가 충분하고 오반응에서 나타나는 처 리과정을 살펴보는 것이 의미있다고 생각하여 시선추적 분석에 오 반응을 추가하여 분석하였다. 이를 통해 실어증 환자가 오반응을 보일 때 나타나는 실시간 처리과정을 살펴보았다는 의의가 있다. 오반응 분석 결과, 능동과 피동 문장에서 모두 ‘대상'을 ‘행위자’보 다 유의하게 더 오랫동안 응시하는 패턴이 나타나지 않아 문장 산 출에 실패한 것으로 보인다. 또한, 능동형 점화 문장 조건에서는 $\mathrm{NP} 1$ 과 NP2 구간에서 통계적으로 유의하게 나타나지는 않았으나 '대상'을 '행위자'보다 많이 응시한 것으로 나타나 정상 성인과 실어 증 정반응의 시선추적 패턴과 비슷한 패턴을 보이고 있어 의미역 
할당의 어려움이 상대적으로 적은 것으로 보인다. 반면, 피동형 점 화 문장 조건에서는 통계적으로 유의하게 나타나지는 않았으나 Before Onset 구간에서 '대상'보다 '행위자를 더 많이 응시하였고, NP1 구간에서 ‘행위자'에 비해 ‘대상’을 유의하게 더 오랫동안 응시 한 것으로 나타나 피동 구문구조에 알맞게 의미역을 처리하는데 어려움이 있음을 확인할 수 있었다. 이는 실어증 환자들이 피동문 의 산출에서 의미역 할당의 어려움을 보인다고 주장한 선행연구와 일치하는 결과이다(Bastiaanse \& Edwards, 2004; Bastiaanse et al., 2003; Caplan \& Hanna, 1998; Faroqi-Shah \& Thompson, 2003).

위와 같은 시선추적 분석 결과를 종합해 볼 때 한국어를 사용하 는 정상 성인 및 실어증 환자의 능동 및 피동 문장을 성공적으로 산 출하는데 있어서 '대상' 의미역에 대한 시선고정이 중요한 역할을 하는 것으로 나타났다. 이와 같은 '대상'을 중심으로 문장을 처리 하는 결과는 Jeong과 Sung (2018)의 연구결과와 맥락을 같이한다. Jeong과 Sung (2018)은 정상 성인 집단과 한국어를 사용하는 실어 증 환자를 대상으로 '동사 선택 과제'를 실시하였다. 그 결과, 동사 선택 과제의 수행력과 유의한 상관관계를 보인 것은 '행위자' 의미 역이 아닌 ‘대상' 의미역으로 나타났다. 또한 동사 및 의미역 처리와 실어증 환자들의 언어 손상 정도 사이에 어떤 관계가 있는지 살펴 본 결과, 동사 선택 과제는 구어 산출 과제와 강한 상관관계가 있는 것으로 나타났다.

영어를 사용하는 정상 성인과 실어증 환자의 능동 및 피동 문장 산출 과정을 살펴본 Mack 등(2017)의 연구에서는 정상 성인의 경 우 말 산출을 하기 전 능동문에서는 '행위자'를, 피동문에서는 '대 상'을 더 오랫동안 응시하여 주어로 오는 의미역을 유의하게 더 많 이 보는 것으로 나타났다. 또한 실어증 환자들의 정반응에서도 정 상 성인과 비슷한 패턴을 보였다고 하였다. 영어는 문장 구조가 주 어-동사-목적어(SVO)로 이루어져 있으며 주어가 문장의 필수 구 성요소이기 때문에 시선추적 결과, 능동과 피동 문장을 산출하기 전 문장 유형과 상관없이 주어로 오는 의미역을 선택하여(능동문 의 경우 ‘행위자', 피동문의 경우 '대상') 더 많이 응시하는 패턴이 나타났다.

반면, 한국어는 문장 구조가 주어-목적어-동사(SOV)로 이루어 져 있으며 주어의 생략이 빈번하게 일어나는 특징을 가지고 있다. 동사가 문장의 마지막에 위치하고 있어 능동문과 피동문을 처리 하는 과정에서 동사의 영향을 많이 받아 능동문과 피동문 모두 '대상' 의미역을 중심으로 처리하는 패턴이 나타났다. 또한, 주어의 생략이 빈번한 만큼 능동문에서는 '행위자' 의미역을 주어로 선택 하는데 인지적 부담이 적어 문장을 산출하기 전 '행위자'와 '대상' 을 비슷하게 응시하다가 문장을 산출하면서 '대상'을 유의하게 더
오랫동안 응시하는 패턴을 보였다고 해석할 수 있다. 피동문에서는 보통 목적어의 자리에 위치하는 '대상' 의미역이 주어의 위치에 오 기 때문에 말 산출을 하기 전에 인지적 부담이 크게 작용하는 '대 상'을 유의하게 더 오랫동안 응시하는 패턴이 나타났다. 이를 통해 한국어의 능동 및 피동 문장의 처리과정이 구문구조의 영향을 받 아 영어의 능동 및 피동 문장의 처리과정과 차이가 있음을 확인할 수 있었다.

본 연구에서 실어증 환자의 경우 능동문의 정반응률이 $48.11 \%$, 피동문의 정반응률이 $31.89 \%$ 로 낮은 정반응률을 보였고, 이러한 산출의 어려움으로 시선추적에 분석에서 제외된 실어증 환자의 수 가 많아 실험 대상자 수가 충분하지 않다는 한계가 있었다. 그러나 이는 영어를 사용하는 실어증 환자(실어증 지수 범위: 53.5-89)를 대상으로 구문 점화 과제에서 능동 및 피동 문장 산출을 본 Mack 등(2017)의 연구와 비슷한 결과로, Mack 등(2017)의 연구에서 실어 증 환자는 능동문에서 $40 \%$, 피동문에서 $10 \%$ 의 정반응률을 보였 으며 낮은 정반응률로 인하여 9 명의 실어증 환자 중 5 명의 시선추 적 자료만이 분석에 사용되었다고 하였다.

또한, 본 연구에 참여한 실어증 환자(실어증 지수 범위: 58.8-91.3) 는 총 9명으로 실험 결과를 실어증 유형별로 나누지는 않았지만 본 연구에 참여한 실어증 환자의 유형을 살펴보면 7명은 유창성 실어 증 환자(명칭실어증, 전도실어증)였고, 2 명의 비유창성 실어증 환자 (브로카실어증)였다. 이 중 비유창성 실어증 환자 2 명 모두 구문 점 화 과제에서 낮은 정반응률을 보였고, 산출 과정에서 큰 어려움을 나타내며 모니터 화면을 잘 보지 않아 시선추적 비율에서 $70 \%$ 미 만을 보여 분석에서 제외되었다. 이러한 경향성을 통해 볼 때, 비유 창성 실어증 환자의 경우 문장 산출에 어려움이 유창성 실어증 환 자에 비하여 더 크며 향후 시선추적을 활용한 문장 산출과 관련된 연구에 참여하는데 어려움이 있을 것으로 보인다.

본 연구의 결과를 종합하여 볼 때, 한국어 실어증 환자는 능동 및 피동 문장 산출에 있어 문장 산출 계획과 실시간 처리과정에서 결함을 보이는 것으로 나타났다. 또한, 한국어를 사용하는 실어증 환자들의 경우 능동 및 피동 문장의 산출에서 '대상' 의미역에 대 한 처리가 문장을 성공적으로 산출하는 데 있어 중요한 요인으로 나타나는 것으로 보인다. 본 연구는 한국어 실어증 환자들을 대상 으로 한 문장 산출 처리과정에 대한 연구로 시선추적기를 활용하 여 정상 성인과 비교하여 실어증 환자의 능동 및 피동 문장 산출의 실시간 처리과정을 파악하고자 하였다는 점에서 의의가 있으며, 향 후 의미역 처리를 강화하는 실어증 환자의 문장 산출과 관련된 중 재 기법 개발에 기여할수 있을 것으로 기대한다. 


\section{REFERENCES}

Bastiaanse, R., \& Edwards, S. (2004). Word order and finiteness in Dutch and English Broca's and Wernicke’s aphasia. Brain and Language, 89(1), 91-107.

Bastiaanse, R., Edwards, S., Mass, E., \& Rispens, J. (2003). Assessing comprehension and production of verbs and sentences: the Verb and Sentence Test (VAST). Aphasiology, 17(1), 49-73.

Bird, H., \& Franklin, S. (1996). Cinderella revisited: a comparison of fluent and non-fluent aphasic speech. Journal of Neurolinguistics, 9(3), 187-206.

Brown-Schmidt, S., \& Tanenhaus, M. K. (2006). Watching the eyes when talking about size: an investigation of message formulation and utterance planning. Journal of Memory and Language, 54(4), 592-609.

Boersma, P., \& Weenink, D. (2018). Praat: doing phonetics by computer (Version 6.0.40) [Computer software]. Retrieved from http://www.fon.hum. uva.nl/praat.

Burchert, F., Meißner, N., \& De Bleser, R. (2008). Production of non- canonical sentences in agrammatic aphasia: limits in representation or rule application?. Brain and language, 104(2), 170-179.

Caplan, D., \& Hanna, J. E. (1998). Sentence production by aphasic patients in a constrained task. Brain and Language, 63(2), 184-218.

Cho, S., \& Thompson, C. K. (2010). What goes wrong during passive sentence production in agrammatic aphasia: an eyetracking study. Aphasiology, 24(12), 1576-1592.

Choi, S. (2012). Comprehension of Active and Passive Sentences in Korean Aphasics: Evidence for Processing Deficit Hypothesis. Communication Sciences \& Disorders, 17(2), 322-337.

Faroqi-Shah, Y., \& Thompson, C. K. (2003). Effect of lexical cues on the production of active and passive sentences in Broca's and Wernicke's aphasia. Brain and language, 85(3), 409-426.

Friedmann, N. A., \& Grodzinsky, Y. (1997). Tense and agreement in agrammatic production: pruning the syntactic tree. Brain and language, 56(3), 397-425.

Griffin, Z. M., \& Bock, K. (2000). What the eyes say about speaking. Psychologicalscience, 11(4), 274-279.

Griffin, Z. M. (2004). Why look? Reasons for speech-related eye movements. In J. M. Henderson \& F. Ferreira (Eds.), The interface of language, vision, and action: eye movements and the visual world (pp. 191-211). New York: Psychology Press.

Holmqvist, K., Nyström, M., Andersson, R., Dewhurst, R., Jarodzka, H., \& Van de Weijer, J. (2011). Eye tracking: a comprehensive guide to methods and measures. Oxford; Oxford University Press.

Jeong, K. H., \& Sung, J. E. (2018). Verbs and their thematic role processing abilities for people with aphasia. Communication Sciences \& Disorders, 23(2), 337-346.

Kang, Y. (2006). A normative study of the Korean-Mini Mental State Examination (K-MMSE) in the elderly. Korean Journal of Psychology: General, 25(2), 1-12.

Kang, Y., Jang, S. M., \& Na, D. L (2012). Seoul Neuropsychological Screening Battery (2nd ed.). Seoul: Human Brain Research \& Consulting.

Kim, Y. (1995). Comprehension processes and structures of Korean relative clause sentences. Korean Journal of Cognitive Science, 6(2), 5-26.

Kim, H., \& Na, D. L. (2012). Paradise-Korean version of Western Aphasia Battery-Revised (PK-WAB_R). Seoul: Paradise Welfare Foundation.

Kolk, H. (1995). A time-based approach to agrammatic production. Brain and language, 50(3), 282-303.

Lee, J., \& Thompson, C. K. (2011). Real-time production of unergative and unaccusative sentences in normal and agrammatic speakers: an eyetracking study. Aphasiology, 25(6-7), 813-825.

Lee, J., Yoshida, M., \& Thompson, C. K. (2015). Grammatical planning units during real-time sentence production in speakers with agrammatic aphasia and healthy speakers. Journal of Speech, Language, and Hearing Research, 58(4), 1182-1194.

Luria, A. R. (1964). Restoration of function after brain injury. Academic Medicine, 39(4), 428.

Mack, J. E., Nerantzini, M., \& Thompson, C. K. (2017). Recovery of sentence production processes following language treatment in aphasia: evidence from eyetracking. Frontiers in human neuroscience, 11, 101.

McNeil, M. R., \& Pratt, S. R. (2001). Defining aphasia: some theoretical and clinical implications of operating from a formal definition. Aphasiology, 15(10-11), 901-911.

Meyer, A. S., \& Lethaus, F. (2004). The use of eye tracking in studies of sentence generation. In J. M. Henderson \& F. Ferreira (Eds.), The interface of language, vision, and action: eye movements and the visual world (pp. 191211). New York: Psychology Press.

Park, C. H. (2012). Statistical approach about ellipsis of Korean and English. Journal of The Society of Korean Language and Literature, 66(0), 171-191.

Park, C. H. (2013). A study of ellipsis in contemporary Korean. Urimal, 32, 39-61.

Rochon, E., Saffran, E. M., Berndt, R. S., \& Schwartz, M. F. (2000). Quantitative analysis of aphasic sentence production: further development and 
new data. Brain and language, 72(3), 193-218.

Saffran, E. M., Berndt, R. S., \& Schwartz, M. F. (1989). The quantitative analysis of agrammatic production: procedure and data. Brain and language, 37(3), 440-479.

Schwartz, M. F., Saffran, E. M., Fink, R. B., Myers, J. L., \& Martin, N. (1994) Mapping therapy: a treatment programme for agrammatism. Aphasiology, $8(1), 19-54$.

Son, B. R. (2001). The influence of thought and culture on language. Modern Studies in English Language \& Literature, 45(2), 131-151.

Sohn, H. M. (2004). Comprehension of reversible passive sentence in Koreanspeaking adults with Broca's aphasia (Master's thesis). Dankook University, Yongin, Korea.

Sung, J. E. (2015). Age-related changes in sentence production abilities and their relation to working-memory capacity: evidence from a verb-final language. PLoS One, 10(4), e0119424.

Sung, J. E., Eom, B., \& Lee, S. E. (2018). Effects of working memory demands on sentence production in aphasia. Journal of Neurolinguistics, 48, 64-75.

Thompson, C. K., \& Choy, J. J. (2009). Pronominal resolution and gap filling in agrammatic aphasia: evidence from eye movements. Journal of psycholinguistic research, 38(3), 255-283.

Thompson, C. K., Dickey, M. W., Cho, S., Lee, J., \& Griffin, Z. (2007). Verb argument structure encoding during sentence production in agrammatic aphasic speakers: an eye-tracking study. Brain and Language, 103(1-2), 2426.

Thompson, C. K., \& Lee, M. (2009). Psych verb production and comprehension in agrammatic Broca's aphasia. Journal of Neurolinguistics, 22(4), 354369.

Thompson, C. K., Meltzer-Asscher, A., Cho, S., Lee, J., Wieneke, C., Weintraub, S., \& Mesulam, M. (2013). Syntactic and morphosyntactic processing in stroke-induced and primary progressive aphasia. Behavioural neurology, 26(1-2), 35-54. 
Appendix 1. 구문 점화 과제의 점화 문장 및 목표 문장 목록

\begin{tabular}{|c|c|c|c|}
\hline 번호 & 문장 유형 & 점화 문장 & 목표 문장 \\
\hline 1 & 능동 & 주황이가 분홍이를 밀다 & 파랑이가 노랑이를 밀다 \\
\hline 2 & 피동 & 분홍이가 주황이에게 묶이다 & 검정이가 노랑이에게 묶이다 \\
\hline 3 & 능동 & 주황이가 분홍이를 끌다 & 노랑이가 파랑이를 끌다 \\
\hline 4 & 피동 & 분홍이가 주황이에게 잡히다 & 검정이가 파랑이에게 잡히다 \\
\hline 5 & 피동 & 주황이가 분홍이에게 차이다 & 노랑이가 파랑이에게 차이다 \\
\hline 6 & 능동 & 주황이가 분홍이를 꺾다 & 검정이가 파랑이를 꺾다 \\
\hline 7 & 능동 & 분홍이가 주황이를 긁다 & 파랑이가 검정이를 긁다 \\
\hline 8 & 피동 & 주황이가 분홍이에게 닦이다 & 노랑이가 검정이에게 닦이다 \\
\hline 9 & 능동 & 주황이가 분홍이를 묶다 & 검정이가 노랑이를 묶다 \\
\hline 10 & 피동 & 분홍이가 주황이에게 쫓기다 & 검정이가 노랑이에게 쫓기다 \\
\hline 11 & 능동 & 주황이가 분홍이를 베다 & 노랑이가 검정이를 베다 \\
\hline 12 & 피동 & 분홍이가 주황이에게 밟히다 & 파랑이가 검정이에게 밟히다 \\
\hline 13 & 피동 & 주황이가 분홍이에게 물리다 & 노랑이가 검정이에게 물리다 \\
\hline 14 & 능동 & 분홍이가 주황이를 흔들다 & 파랑이가 검정이를 흔들다 \\
\hline 15 & 피동 & 분홍이가 주황이에게 꺾이다 & 검정이가 파랑이에게 꺾이다 \\
\hline 16 & 피동 & 주황이가 분홍이에게 긁히다 & 파랑이가 검정이에게 긁히다 \\
\hline 17 & 능동 & 주황이가 분홍이를 잡다 & 검정이가 파랑이를 잡다 \\
\hline 18 & 능동 & 분홍이가 주황이를 닦다 & 노랑이가 검정이를 닦다 \\
\hline 19 & 피동 & 분홍이가 주황이에게 베이다 & 노랑이가 검정이에게 베이다 \\
\hline 20 & 피동 & 주황이가 분홍이에게 꼬집히다 & 파랑이가 노랑이에게 꼬집히다 \\
\hline 21 & 능동 & 주황이가 분홍이를 쫓다 & 검정이가 노랑이를 쫓다 \\
\hline 22 & 능동 & 분홍이가 주황이를 찌르다 & 검정이가 노랑이를 찌르다 \\
\hline 23 & 피동 & 주황이가 분홍이에게 흔들리다 & 파랑이가 검정이에게 흔들리다 \\
\hline 24 & 피동 & 분홍이가 주황이에게 끌리다 & 노랑이가 파랑이에게 끌리다 \\
\hline 25 & 능동 & 분홍이가 주황이를 물다 & 노랑이가 검정이를 물다 \\
\hline 26 & 능동 & 주황이가 분홍이를 밟다 & 파랑이가 검정이를 밟다 \\
\hline 27 & 피동 & 분홍이가 주황이에게 밀리다 & 파랑이가 노랑이에게 밀리다 \\
\hline 28 & 능동 & 분홍이가 주황이를 차다 & 노랑이가 파랑이를 차다 \\
\hline 29 & 피동 & 주황이가 분홍이에게 찔리다 & 검정이가 노랑이에게 찔리다 \\
\hline 30 & 능동 & 분홍이가 주황이를 꼬집다 & 파랑이가 노랑이를 꼬집다 \\
\hline
\end{tabular}


Appendix 2. 구문 점화 과제의 오류 유형 및 예시

\begin{tabular}{lll}
\hline 오류 유형 & \multicolumn{1}{c}{ 정의 } & 오류 예시(정반응: 파랑이가 노랑이에게 밀리다) \\
\hline 조사 & 조사의 사용이 적절하지 못한 경우(생략, 대치 등) & 파랑이에게 노랑이에게 밀리다 \\
의미역 전환 & 행위자와 대상의 전환 & 노랑이가 파랑이에게 밀리다 \\
문장 유형 전환 & 같은 의미의 능동형 문장 산출(능동형의 경우 같은 의미의 피동형 문장 산출) & 노랑이가 파랑이를 밀다 \\
기타 & 불완전하게 산출된 문장, 무반응, 두 가지 오류 이상의 복합오류를 보인 경우 등 & 파랑이를 밀다 \\
& 노랑이를 파랑이에게 밀리다 \\
\hline
\end{tabular}

Appendix 3. 집단 간 능동 및 피동 문장 산출 정확도에 대한 평균과 표준편차

\begin{tabular}{lcccccc}
\hline & \multicolumn{2}{c}{ 정상 성인 $(\mathrm{N}=10)$} & & \multicolumn{2}{c}{ 실어증 환자 $(\mathrm{N}=9)$} \\
\cline { 2 - 3 } \cline { 6 - 7 } \cline { 6 - 7 } & 평균 & 표준편차 & & 평균 & 표준편차 \\
\hline 능동문 $(\%)$ & 100 & 0 & & 48.11 & 35.06 \\
피동문 $(\%)$ & 100 & 0 & & 31.89 & 42.48 \\
\hline
\end{tabular}

Appendix 4. 집단 간 능동 및 피동 문장 산출 소요시간에 대한 평균과 표준편차

\begin{tabular}{lcccccc}
\hline & \multicolumn{2}{c}{ 정상 성인 $(\mathrm{N}=10)$} & & \multicolumn{2}{c}{ 실어증 환자 $(\mathrm{N}=9)$} \\
\cline { 2 - 3 } \cline { 6 - 7 } \cline { 6 - 7 } & 평균 & 표준편차 & & 평균 & 표준편차 \\
\hline 능동문 $(\mathrm{s})$ & 1.28 & 0.22 & & 3.80 & 1.49 \\
피동문 $(\mathrm{s})$ & 1.21 & 0.17 & & 3.37 & 1.02 \\
\hline
\end{tabular}

Appendix 5. 문장 산출 구간별 관심 영역(행위자, 대상)의 시선고정 횟수에 대한 평균과 표준편차

\begin{tabular}{|c|c|c|c|c|c|c|c|c|}
\hline \multirow{2}{*}{$\begin{array}{l}\text { 문장 산출 구간 } \\
\text { 관심 영역 (AOI) }\end{array}$} & \multicolumn{2}{|c|}{ Before Onset } & \multicolumn{2}{|c|}{ NP1 } & \multicolumn{2}{|c|}{ NP2 } & \multicolumn{2}{|c|}{ V-End } \\
\hline & 행위자 & 대상 & 행위자 & 대상 & 행위자 & 대상 & 행위자 & 대상 \\
\hline \multicolumn{9}{|l|}{ 능동문 } \\
\hline 정상 성인 $(\mathrm{N}=10)$ & $2.07(0.62)$ & $1.85(0.64)$ & $0.35(0.21)$ & $1.68(0.41)$ & $0.42(0.24)$ & $1.39(0.46)$ & $0.53(0.16)$ & $0.79(0.37)$ \\
\hline 실어증 정반응 $(\mathrm{N}=7)$ & $4.89(1.09)$ & $3.89(1.57)$ & $1.12(0.61)$ & $3.88(2.12)$ & $0.96(0.58)$ & $2.93(1.82)$ & $0.59(0.45)$ & $0.78(0.55)$ \\
\hline 실어증 오반응 $(N=7)$ & $4.93(3.16)$ & $4.52(2.30)$ & $1.59(1.50)$ & $2.65(2.06)$ & $0.98(0.96)$ & 2.05 (1.39) & $0.47(0.39)$ & $1.09(0.94)$ \\
\hline \multicolumn{9}{|l|}{ 피동문 } \\
\hline 정상 성인 $(\mathrm{N}=10)$ & $1.01(0.83)$ & $2.72(0.63)$ & $1.39(0.52)$ & $0.89(0.59)$ & $0.93(0.49)$ & $1.26(0.55)$ & $0.51(0.27)$ & $0.99(0.47)$ \\
\hline 실어증 정반응 $(\mathrm{N}=5)$ & $2.59(1.20)$ & $5.51(1.12)$ & $1.90(1.25)$ & $2.31(2.07)$ & $1.40(0.45)$ & $1.97(0.76)$ & $0.35(0.32)$ & $0.70(0.52)$ \\
\hline 실어증 오반응 $(\mathrm{N}=5)$ & $4.99(0.97)$ & $3.72(1.42)$ & $1.36(1.29)$ & $3.38(2.27)$ & $1.33(0.83)$ & $2.69(1.92)$ & $0.79(0.82)$ & $1.01(0.60)$ \\
\hline
\end{tabular}

Values are presented as mean (SD).

$\mathrm{NP}=$ Noun Phrase; $\mathrm{V}$-End=Verb-End; $\mathrm{AOI}=$ areas of interest. 


\title{
국문초록
}

\author{
시선추적을 활용한 구문 점화 과제에서 실어증 환자의 능동 및 피동 문장 산출 능력 \\ 신미경 · 성지은 \\ 이화여자대학교 언어병리학과
}

배경 및 목적: 본 연구는 구문 점화 과제에서 정상 성인과 실어증 환자의 능동 및 피동 문장 산출 과정을 시선추적기를 활용하여 분석 해 봄으로써 실어증 환자의 능동문과 피동문 산출 능력에 대해 알아보고자 하였다. 방법: 본 연구의 대상자는 실어증 환자 9 명과 정상 성인 10 명이었다. 동일한 구문구조의 점화 문장을 먼저 제시하여 목표 문장의 산출을 촉진하는 구문 점화 과제를 사용하였다. 정반응 률과 문장 산출 반응시간이 분석되었으며, 시선추적 분석은 문장 산출 구간(Before onset, NP1, NP2, V-End)별로 관심 영역(행위자, 대 상)에 대한 시선고정 횟수가 분석되었다. 결과: 실어증 환자는 능동문과 피동문 산출에서 정상 성인에 비해 정반응률이 유의하게 낮았 고, 문장을 산출하는데 유의하게 더 오랜 시간이 걸리는 것으로 나타났다. 시선추적 분석 결과, 능동 및 피동형 점화 문장 조건에서 실 어증 환자의 정반응은 정상 성인의 정반응과 비슷한 시선고정 패턴을 보이는 것으로 나타났으나, 실어증 환자의 오반응은 정상 성인과 실어증 환자의 정반응에서 나타나는 시선고정 패턴과 다르게 나타났다. 논의 및 결론: 실시간 처리과정을 살펴본 결과, 실어증 환자들 은 능동문과 피동문 산출에 있어서 정반응을 할 때 정상 성인의 정반응과 유사하게 ‘대상'을 ‘행위자'보다 유의하게 더 오랫동안 응시하 는 시선고정 패턴을 보이지만, 오반응을 할 때에는 이와 같은 시선고정 패턴이 나타나지 않아 실어증 환자들에게서 나타나는 문장처리 의 어려움을 확인할 수 있었다.

핵심어: 시선추적, 능동 및 피동 문장 산출, 실어증, 구문 점화

이 논문은 2019 년 대한민국 교육부와 한국연구재단의 지원을 받아 수행된 연구임(NRF-2019R1A2C1089280).

이 논문은 2019년 한국언어청각임상학회 이승환장학금 지원에 의한 연구임.

\section{참고문헌}

강연욱(2006). K-MMSE (Korean-mini mental state examination)의 노인 규준 연구. 한국심리학회지: 일반, 25(2), 1-12.

강연욱, 장승민, 나덕렬(2012). 서울신경심리검사 2판(SNSB-D). 인천: 휴브알엔씨.

김영진(1995). 한국어 관계절 문장의 이해 과정과 구조. 인지과학, 6(2), 5-26.

김향희, 나덕렬(2012). 한국판 웨스턴 실어증 검사-개정판. 서울: 파라다이스 복지재단.

박청희(2012). 한국어와 영어의 생략 현상에 대한 통계적 접근. 어문논집, 66(0), 171-191.

박청희(2013). 주어와 서술어의 생략 현상 연구. 우리말연구, 32, 39-61.

손병룡(2001). 사고와 문화가 언어에 미치는 영향. 현대영어영문학, 45(2), 131-151.

손혜민(2004).브로카 실어증 환자의 피동문 이해. 단국대학교 대학원 석사학위논문.

정귀현, 성지은(2018). 의미역 유형에 따른 실어증 환자의 동사 및 의미역 처리 능력과 중증도 간의 관계. Communication Sciences \& Disorders,

23(2), 337-346.

최소영(2012). 한국 실어증 환자의 능 - 피동문 이해: 처리 손상 관점의 접근 언어청각장애연구, 17(2), 322-337.

\section{ORCID}

신미경(제1저자, 대학원생 http://orcid.org/0000-0003-1716-7993); 성지은(교신저자, 교수 http://orcid.org/0000-0002-1734-0058) 